CASTILLO Gómez, Antonio.

\title{
Livros e leituras na Espanha do Século de Ouro. Prefácio Marisa Midori Deaecto, tradução Claudio Giordano. Cotia, SP: Ateliê Editorial, 2014, 208p.
}

\author{
Eduardo Santos NeumanN \\ Pós-Graduação em História \\ Universidade Federal do Rio Grande do Sul \\ Rua Ivan Iglesias 184, Porto Alegre, RS, 91.210-340, Brasil \\ eduardosneumann@gmail.com
}

Enhorabuena, esta expressão tão castelhana - que felicita uma realização ou parabeniza um determinado feito -, sintetiza de maneira apropriada a publicação em língua portuguesa de mais um livro do historiador, especialista em cultura escrita, Antonio Castillo Gómez. Este é o primeiro livro de Castillo publicado no Brasil, apesar do autor já possuir diversos artigos e capítulos de livros em periódicos e obras coletivas editadas em nosso país.

Desde a conclusão de sua tese de doutorado, publicada em 1997, ele tem direcionado seus esforços para consolidar uma linha de pesquisa cuja atenção está voltada aos materiais escritos, particularmente aqueles produzidos na sociedade hispânica durante os séculos XVI e XVII. É nesse contexto, o Século de Ouro espanhol, que está situado este livro.

A seleção de textos reunidos nesta obra, uma compilação de trabalhos reelaborados e atualizados, são o resultado da trajetória de um pesquisador maduro e interessado em rastrear as distintas práticas da leitura apesar de suas pistas difusas, pois esta é uma atividade plural.

Recebido: 29 de outubro de 2015 | Aprovado: 3 de novembro de 2015

http://dx.doi.org/10.1590/0104-87752016000100012

Varia Historia, Belo Horizonte, vol. 32, n. 58, p. 265-268, jan/abr 2016 
É consenso entre os historiadores que o advento da Idade Moderna marca o ingresso definitivo da sociedade ocidental europeia nas práticas da comunicação letrada, período no qual é registrada uma ampliação das taxas de alfabetização e do número de livros impressos. Assim, as indagações do autor estão direcionadas às práticas de leitura na sociedade castelhana, com ênfase nas suas diferentes modalidades e experiências, seja a leitura erudita ou aquela praticada por pessoas comuns que mantinham contato esporádico com a cultura escrita, fosse através de uma gazeta, um panfleto ou mesmos as escritas expostas ou cartazes fixados nas portas das igrejas.

Afinal, no que consiste atualmente história da leitura? Para responder a esta indagação e necessário inseri-la na perspectiva da história social da cultura escrita. Quando surge este novo campo de estudo? Primeiro: tratase de um termo recente, cunhado em meados dos anos 90, e designa um campo de investigação fértil, que tem conferido sinais de vitalidade à pesquisa histórica. A segunda consideração diz respeito a sua formulação. Sua gênese está relacionada a recuperação ou as reconsiderações em torno da leitura e principalmente da escrita como objeto de análise histórica, mudança iniciada nos anos 60. E a escrita e suas potencialidades tem em Armando Petrucci, paleógrafo italiano, o principal expoente dessa renovação. Ao propor uma "ciência da escrita" ele argumenta que os textos podem revelar além do seu conteúdo expresso, os valores e condutas de uma época. A partir da fusão de duas vertentes - no caso a história social da escrita e a história do livro e da leitura -, cuja reformulação permitiu uma renovação dos pressupostos teóricos e metodológicos que pautava tais temas, tais modificações conferiram ao estudo da escrita e da leitura um ponto de observação privilegiado para a compreensão das sociedades pretéritas.

O livro no seu conjunto está organizado em 6 partes. No primeiro capítulo, o autor aborda os diferentes significados da leitura na sociedade hispânica - o que se lia, como liam e as avaliações a respeito desse habito-, pois como registrou Miguel de Cervantes, através de seu imortal personagem, Dom Quixote, do qual se dizia que de "tanto ler secaria o cérebro". No segundo dedica atenção a leitura erudita, a leitura por 
excelência nas avaliações mais tradicionais sobre o tema, e seu vínculo imediato com a escrita. O terceiro "Paixões solitárias", apresenta um estudo sobre as práticas de leitura daqueles indivíduos privados de liberdade, que exatamente pela reclusão atrás das grades, buscavam na leitura um alento. No quarto capitulo "Ler em comunidade" trata das leituras femininas, particularmente aquelas realizadas por religiosas efetuadas em conventos, no caso a leitura de textos espirituais que tem nas monjas carmelitas descalças, seguidoras de Santa Teresa de Jesús, seu exemplo maior. Nos capítulos finais, Castillo dedica atenção a dois temas de sua predileção: as práticas leitoras cotidianas e o contato estabelecido com a leitura nas ruas, através de folhetos, avisos ou mesmo os pasquins infamantes. O último capítulo é dedicado ao contato com os livros e a leitura. Analisa como esta prática despertou em alguns o desejo de se converter também em autores, seja através da redação de diários ou de "autobiografias", uma manifestação de uma memória pessoal.

Pelo exposto e evidente que diante da primazia da cultura letrada durante o Século de Ouro espanhol a leitura e a escrita promoveram transformações que afetaram tanto as formas de organização política como as relações sociais. Sem dúvida, a prática da escrita e da leitura foi mais acentuada nos espaços régios, nos círculos cortesãos, mas também estava presente nas oficinas dos artesãos e mesmo nas ruas. Em seus trabalhos o autor tem procurando descrever através da análise dos materiais escritos, tanto os permanentes ou efêmeros, os significados relacionados à presença da leitura e da escrita, indagando a respeito dos efeitos da alfabetização entre as camadas médias e subalternas.

Ao contemplar a atividade de leitores particularmente nos espaços urbanos Antonio Castillo centra atenção àqueles que ao transgrediram as normas vigentes, fizeram outros usos da leitura. Afinal, não saber ler não implicava obrigatoriamente estar excluído do mundo da cultura escrita, e muitos indivíduos ao compartilharem a leitura com os demais utilizaram-na para finalidades distintas. O foco são os outros leitores. As leituras realizadas pelos grupos menos favorecidos, que nos espaços públicos entram em contato com os textos lidos de forma coletiva, independente do fato de serem escutadas ou lidas, permitiram aos distintos 
públicos contato com os últimos acontecimentos ou mesmo o conteúdo das edições recentes.

No seu conjunto a análise morfológica dos produtos escritos, dos textos manuscritos, está voltada a reconstruir as possíveis conexões existentes entre as diferentes práticas letradas e seus contextos sociais de recepção. Esta é uma das particularidades presentes a história social da cultura escrita, ou seja, uma interpretação pautada em evidências, na constituição de um corpus documental.

Por suas inquietações Antonio Castillo Goméz não se rende às explicações simplistas a respeito dos recortes sociais em sociedades de Antigo Regime. Seu interesse são aqueles grupos cujas evidências de sua capacidade alfabética, apesar de mais esparsas, comprovam a abrangência social da leitura. E a escrita, apesar de suas implicações imediatas com o poder, nem sempre remete obrigatoriamente a uma leitura elitista da sociedade e seu estudo têm sinalizado outras indagações a respeito do consumo cultural. Enhorabuena, repito, os leitores brasileiros agora têm ao seu alcance este excelente conjunto de textos. 